\title{
Transition and Opportunity: Investing in and Benefiting from China's New Development Paradigm
}

\author{
Vaughn Barber
}

\begin{abstract}
China is frequently ranked as one of the most important markets for multinational companies ( $M N C s$ ), having passed the US as the top destination for new foreign investment in 2020. There are five factors that have contributed to this, including market size, innovation, the role of foreign investment, supportive policies and access to markets beyond China. Other opportunities created by China include the Belt and Road Initiative, digital transformation and its low-carbon economy. We are at an inflexion point in China's transition and integration in the world economy with both new opportunities and challenges.
\end{abstract}

Keywords MNCs • Market size - Innovation • Role of foreign investment • Supportive policies $\cdot$ Belt and road initiative $\cdot$ Digital transformation $\cdot$ Low-carbon economy

In surveys by foreign chambers of commerce in China, China is frequently ranked as one of the most important markets for multinational companies (MNCs). This is also consistent with China being one of the world's major FDI recipients having passed the US as the top destination for new foreign investment in 2020. The following five factors mean that China will continue to offer significant opportunities for foreign companies as it works to achieve the objectives laid out in The Outline of the 14th Five-Year Plan (2021-2025) for National Economic and Social Development and the Long-Range Objectives Through the Year 2035 (the Plan), which was approved at the annual session of China's top legislature in March 2021.

The views expressed in this article are those of the author and do not necessarily reflect the views of any entity or organization with which he is affiliated.

\author{
V. Barber $(\bowtie)$ \\ KPMG China, Beijing, China \\ China-Australia Chamber of Commerce, Beijing, China
}




\section{Market Size}

Global trade with China has grown significantly over the past two decades, particularly in emerging markets. China has also become a top recipient of foreign direct investment globally. These developments have been driven by the growth of China's economy. Looking forward, steady growth and expectations that China's economy will double in size by 2035; mean trade and investment will continue to grow.

China already has 400 million middle-class consumers, with this number forecast to double by 2030 , and China is on track to become the world's largest consumer market. As per capita, disposable incomes increase, household spending is shifting from focusing solely on satisfying basic needs to discretionary items. This brings significant opportunities in the sectors that cater to the needs and preferences of China's "new consumer class".

China also has the world's largest elderly population. According to the recently released results of China's seventh national population census, there are 264 million people aged 60 and over and 191 million aged 65 and over, representing 18.7 and $13.5 \%$ of the total population, respectively. These figures are forecast to increase to nearly 500 million and 370 million by 2050 , representing approximately 38 and $30 \%$ of the total population. By any measure, the size of the market opportunity this represents is significant. By 2050, the purchasing power of China's elderly will be more than USD 16 trillion ${ }^{1}$ which would make China one of the world's largest elder care markets. Over the next decade, the elder care sector itself is forecast to grow to almost USD 2 trillion. ${ }^{2}$ This portends significant growth in demand for health and elderly care services, medical equipment and products for the elderly and associated infrastructure, driven by the needs of an aging demographic and rising middle-class expectations and supported by government policies.

For many sectors, the size of the market in China means that MNCs cannot be "leaders" without being successful in China. Business sentiment surveys undertaken by foreign chambers of commerce in China reflect the importance of China for MNCs in terms of contribution to global sales and global profit. This trend will continue and increase as growth and innovation continue at pace in China, supported by continued reforms and market opening.

The emergence of the "dual circulation" strategy has prompted questions about the extent to which these market opportunities will continue to be available to foreign companies. "Dual circulation" refers to a new development paradigm with domestic circulation as the mainstay and domestic and international markets reinforcing each other. Against the backdrop of an increasingly challenging external environment due to the disruptions brought by COVID-19 and geopolitical tensions, it is only natural that China is looking to "fully bring out the advantage of China's super-large market

\footnotetext{
1 "China Report of the Development on Silver Industry (2014)", Social Sciences Academic Press, September 2014.

2"China 2016 White Paper on the Development of Senior Care Industry", Chinese Academy of Social Sciences.
} 
scale and the potential of domestic demand" and make the domestic market the main driver of its overall growth.

But this does not mean that China is shutting its door. On the occasion of the China International Import Expo in November 2020, President Xi said: "our aim is to turn the China market into a market for the world, a market shared by all, and a market accessible to all... What we envision is not a development loop behind closed doors, but more open domestic and international circulation." 3 This has been emphasized often since the "dual circulation" strategy was first announced and is embedded into the Plan.

\section{Innovation}

Innovation is at the center of efforts to modernize China's industrial system and boost scientific and technological self-reliance. Innovation is critical for China to improve productivity and achieve its economic growth targets.

The size of the consumer market, industrial base and availability of lower cost $\mathrm{R} \& \mathrm{D}$ talent provide cost and speed advantages for China to become a leader in global innovation.

By way of example, China's potential for technology innovation can be seen in the results of KPMG's annual survey of global technology leaders undertaken in 2020 where four major cities in China-Shanghai, Beijing, Hong Kong SAR and Shenzhen-were ranked among the top 20 leading technology innovation hubs outside Silicon Valley/San Francisco over the next four years. ${ }^{4}$ The US and China have been ranked first and second, respectively, for the past several years in terms of countries which show the most promise for developing globally impactful disruptive technologies.

China is taking comprehensive actions to develop its own domestic innovation ecosystem and encourage companies to increase their R\&D spending and pursue innovation-driven development. China is developing Beijing, Shanghai and the Guangdong-Hong Kong-Macao Greater Bay Area into global science and technology innovation hubs. It is expected that science and technology innovation will be a feature of regional development plans and other national initiatives, to increase the global competitiveness of Chinese industry.

Technological disruption has become the new normal, with most China CEOs seeing technological disruption as more of an opportunity than a threat. In KPMG's 2019 Global CEO Survey, seven in 10 China CEOs said their companies' ability to grow relies on their ability to challenge and disrupt business norms, while more than

\footnotetext{
${ }^{3}$ Keynote Speech by H.E. Xi Jinping President of the People's Republic of China At the Opening Ceremony of The Third China International Import Expo, Beijing, 4 November 2020.

${ }^{4}$ https://home.kpmg/content/dam/kpmg/us/pdf/2020/03/tech-innovation-hubs-2020.pdf.
} 
half of the China CEOs said their companies are actively disrupting the sectors in which they operate, rather than waiting to be disrupted. ${ }^{5}$

Given these trends and underlying drivers, participating in innovative development in China will be increasingly important for MNCs to maintain their competitiveness in China and other markets around the world, with China offering scale, cost and speed advantages for developing and commercializing new technologies and business models.

MNCs may consider partnering strategies such as "setting up accelerator or incubator programs for start-up firms", "joining industry consortia focused on development of innovative technologies" and "collaborating with innovative start-ups (e.g., Fintech, InsurTech, HealthTech firms)". These were selected by more than half the China CEOs in KPMG's 2019 Global CEO Survey as actions they planned to undertake over the 2019-2022 time period to help pursue their organization's growth objectives.

\section{Role of Foreign Investment}

Foreign investment will continue to play an important role in China's new development paradigm. With an emphasis on achieving high-quality development that is "more efficient, equitable, sustainable and secure", there will be opportunities for foreign investment: (1) to support industrial upgrading including through the supply of capital, advanced technologies, management and operating experience; (2) to satisfy the demand of Chinese consumers; and (3) to support China's transition into an innovation-intensive, consumption-led economy. At the same time, it is important that investors understand how the advantages which China offers as an investment destination have changed. These changes and the practical implications for foreign companies investing in China are discussed further in KPMG's China Outlook $2018{ }^{6}$

\section{Supportive Policies}

China will continue to open-up its economy, particularly in relation to the services sector, launch more comprehensive trials and formulate a negative list for crossborder trade in services. In addition to reducing the negative list, China will encourage foreign companies to invest in advanced manufacturing, in new and high technologies, in the energy conservation and environmental protection industries, and in the central and western regions. Free Trade Zones will be used to pilot new ways of

\footnotetext{
${ }^{5}$ https://assets.kpmg/content/dam/kpmg/cn/pdf/en/2019/06/2019-china-ceo-outlook.pdf. ${ }^{6} \mathrm{https}: / /$ assets.kpmg/content/dam/kpmg/cn/pdf/en/2019/06/2019-china-ceo-outlook.pdf, pp. 5056.
} 
opening-up, with high-quality opening-up being necessary to promote high-quality development.

China continues to prioritize fostering a world-class, market-oriented business environment governed by a sound legal framework. An important element of this is supporting fair competition on a level playing field, including equal treatment of all companies and equal protection of property rights, particularly protection of intellectual property rights for all market participants.

Efforts by China to modernize its domestic economy and governance systems including to benchmark and align with international rules, standards and practices will be conducive to foreign companies carrying on business in China. At the same time, it will also mean that Chinese companies will be able to operate more effectively in overseas markets.

Data is a key factor of production in the digital economy. China is working on a data governance framework the objective of which is to fully realize the value of data in the economy. Measures will include establishing rules for determining ownership, transferring, using and protecting data, as well as strengthening personal data protections; measures to promote healthy competition, prevent monopolies and strengthen regulatory supervision; and creating mechanisms for more sharing of public data from government authorities including pilot programs where third parties are authorized to operate government data, which will encourage greater mining and use of public data.

\section{Access to Markets Beyond China}

Efforts to facilitate and reduce the cost of cross-border transactions increase the attractiveness of using China as a headquarter from which to access and serve markets across Asia and countries along the Belt and Road. Implementation of the China-EU Comprehensive Agreement on Investment will also be conducive to EU companies investing in China and being able to access these benefits.

Last year, 10 ASEAN countries, China, Japan, the Republic of Korea, Australia and New Zealand concluded the Regional Comprehensive Economic Partnership (RCEP). RCEP is the world's largest free trade agreement, representing approximately $30 \%$ of the world economy and $30 \%$ of the world's population. In 2020 , China's exports to RCEP15 accounted for $27 \%$ of China's total exports and $37.8 \%$ of the country's total imports. As the first and only trade agreement between China, Japan and the Republic of Korea (ROK), the agreement will support supply chain stability in South East Asia where economies are highly dependent on trade. The rules of origin, which are based on total value add in the region (under the so-called regional accumulation rule), will encourage expanding and deepening supply chains in the region. After the agreement enters into force, an expected increase in trade in goods will lead to a growth of trade in services related to goods trade, for example 
warehousing, transportation, financial settlement, financing, insurance, etc. Crossborder trade in services, particularly internet-enabled services will also see further growth due to the implementation of commitments under the RCEP.

After the RCEP comes into force, about 35\% of China's trade will be with Free Trade Agreement partners. China has said that it will accelerate the negotiation of the China-Japan-ROK Free Trade Agreement and will progress negotiations with The Gulf Cooperation Council, Norway and Israel. China is also actively considering joining the Comprehensive and Progressive Agreement for Trans-Pacific Partnership (CPTPP).

The actions that will be taken around promoting "high quality" BRI development will also make China an ideal location from which to export to and invest in BRI countries.

\section{Opportunities for Foreign Companies}

Foreign companies should study the contents of the Plan as well as relevant provincial, municipal and sectoral plans that have been and will be released describing the targets in more detail as well as the actions which will be taken to achieve them. Here are some of the areas where there are or will be significant opportunities for foreign companies.

\subsection{Belt and Road Initiative}

The Plan sets a clear direction for the promotion of "high quality" development under the Belt and Road Initiative (BRI). The ongoing "marketization" of these projects including through partnering with international private capital, following international practices and debt sustainability principles, and increased focus on risk management and legal and contractual protections, will all support the objective of increasing and diversifying funding sources including from multilateral and global financial institutions. This will also increase opportunities for MNCs to invest in and supply goods and services to these projects. The Plan also talks about promoting ecommerce and international co-operation in industrial projects in BRI markets, with priority being given to co-operation in digital, green and health-related projects.

Chinese companies will increasingly adopt applicable environmental, social and governance (ESG) standards and best practices in delivering and financing "sustainable" BRI projects. In the post-pandemic era, with less financial capacity to invest in new infrastructure projects we expect host country governments will increasingly look to tap private capital to provide infrastructure project financing. At the same time, if companies want to borrow money from international financial institutions or raise investment from international investors, compliance with ESG principles is mandatory. That is to say that providers of public and private capital will require 
project developers to comply with ESG laws and adopt ESG standards in the planning, construction and operation phases of infrastructure projects. This will give rise to new opportunities for collaboration between Chinese and foreign companies. This new development paradigm in China will encourage synergistic development of inward investment to China and outward investment from China. This means that inward investments should also be considered in terms of their ability to create or enhance outward trade and investment opportunities. In this regard, opportunities for experience gained partnering and working with Chinese companies on "high quality" projects in China can be applied and replicated in other international markets in multiple sectors. Some MNCs and international investors have already shown that successful collaboration on projects in China can be replicated in other countries. More instances of successful international collaboration on projects in China will be conducive to these business partnerships being "exported" to and applied on projects in third country markets.

Consistent with this, foreign investors should monitor the progress of reforms to mobilize private investment in projects, the development of PPPs in China and the use of Real Estate Investment Trusts to hold infrastructure assets to identify suitable opportunities to participate through equity investment and/or loan financing including green bonds.

\subsection{Digital China}

Digital development is a key focus of the Plan with digital transformation set to drive changes in production, lifestyle and governance in China.

Traditional infrastructure has supported China's emergence as a global manufacturing powerhouse. Now China is working to tap the significant potential for digitalization and technological innovation to create demand, drive productivity gains and improve resilience and environmental sustainability across all industries and sectors in China with "new infrastructure" being the backbone to deliver these economic, social and environmental benefits. We see this across three main dimensions.

First, digitalization has become a key driver and enabler of transformation, helping companies boost productivity, unlock new demand and improve their capacity to provide high quality, environmentally friendly and value-for-money goods and services to customers at home and abroad. These efforts will also be an important way to deal with impacts of a shrinking labor force. Second, digitalization is driving the innovation and disruption of industries. Third, there is great potential for data and digital technologies to deliver better liveability, sustainability and economic outcomes in "smarter" cities, where "technology" and "applications and data analytics" connect the physical infrastructure with users, to improve quality of life across different areas.

Digital technologies will be highly integrated with the real economy, helping traditional industries to upgrade and fostering the emergence of new industries, new types of business and new business models. The Plan highlights cloud computing, 
big data, IoT (particularly for automobiles, medical devices and home appliances), industrial internet (particularly for intelligent manufacturing), blockchain, artificial intelligence, and virtual reality or augmented reality as seven key sectors. On the demand side, more public services will incorporate digital delivery to improve accessibility and convenience including education, medical and elder care. All aspects of daily life will become more digital including consumer spending, home life, tourism and leisure, transport etc. As in other sectors, there is great potential for China's experience in digitalization and business model innovation to be exported to and applied in other countries, particularly in emerging markets.

\subsection{Green, Low Carbon Economy}

President Xi's pledge that China will be carbon neutral by 2060 was welcomed by and has already attracted considerable attention from the international community. The transition to a green economy will bring significant opportunities for companies and institutions that move quickly to establish leading capabilities in providing solutions compatible with low-carbon growth.

Goldman Sachs estimates a total "green" infrastructure investment opportunity of USD 16 trillion by 2060 across power generation, transport infrastructure for electric vehicles, carbon sequestration and hydrogen infrastructure for transport, industry and heating, of which they estimate that at least $75 \%$ should come from the private sector. ${ }^{7}$

Efforts to develop the green economy in China will also see demand for "green" equipment, technology, services and investment grow at a fast pace. There will be opportunities in areas such as environmental protection, renewable energy, green materials, advanced composites, new energy vehicles, recyclables and green financing.

These are all areas where foreign companies can share their experience of developing and implementing new approaches and technologies to reduce the climate impact of economic and social activity. For foreign suppliers, the China market offers scale to develop and commercialize new technologies and innovative solutions. And successful project experience in China can be applied and replicated in other countries.

Consulting firms and NGOs will have significant opportunities to help companies in China to develop and implement responsible and sustainable strategies, business models, operations and investments; to develop business models, products and services that address climate change and help companies reduce carbon emissions; to design governance frameworks, processes, methods, tools and metrics to better track, measure, manage and report on ESG performance; and to provide assurance around ESG disclosures including environmental benefits disclosures.

There is growing optimism that ecological interdependence will give rise to international cooperation in climate change. Much has been said about the potential for and

\footnotetext{
7“Carbonomics: China net zero: The clean tech revolution”, Goldman Sachs, 21 January 2021.
} 
necessity of collaboration between China and the US to combat climate change. The "China-US Joint Statement Addressing the Climate Crisis" provides an initial indication of the areas where the two countries have said they "are committed to cooperating with each other and with other countries to tackle the climate crisis". There will also be considerable synergies from cooperation between China and the UK. Indeed, it is hard to imagine the UK could achieve the ambitious goals which the government outlined in its plan for a "Green Industrial Revolution" without cooperating with Chinese companies to unlock the capital, technology, R\&D and scale advantages they bring to the table. Likewise, for UK companies, Chinese demand for leading technology, solutions and experience could support the creation of more high-skilled jobs, narrow the "chasm between invention and application" necessary to fund continued innovation. Similar synergies as these will exist with other advanced economies, including to partner in helping developing economies to tackle climate change.

Development, deployment and use of clean technologies in both developed and developing countries will be key to addressing climate change. It is important that efforts are taken to guard against balkanization of these technologies and ecosystems. This is because, ceteris paribus, access to a greater market demand which globalization of climate technologies and solutions would provide, would be expected to support more and earlier private investment in innovation. At the same time, however, the way in which these technologies are developed, deployed and used will also need to be responsive to host country expectations about building local industries and creating local employment, rather than only striving to deliver low-cost production. As with policy announcements in the UK, President Biden's address to a joint session of congress on 28 April 2021 talked about the importance of creating local employment:

For too long, we have failed to use the most important word when it comes to meeting the climate crisis. Jobs. Jobs. Jobs. For me, when I think about climate change, I think jobs...

There's no reason the blades for wind turbines can't be built in Pittsburgh instead of Beijing. No reason why American worker's can't lead the world in the production of electric vehicles and batteries.

Multilateral coordination will be needed to ensure the benefits of the economic activity undertaken to develop, deploy and use climate-friendly technologies are shared between and within countries in an equitable manner to avoid exacerbating the imbalances that have fueled the backlash against economic globalization and rising populism and protectionism.

\footnotetext{
${ }^{8}$ Speech by Prime Minister The Rt Hon Boris Johnson MP delivered on 30 June 2020 in Dudley.
} 


\subsection{Development of Regional Economies}

Efforts to promote coordinated development between urban and rural areas and between different regions within China will enable foreign companies to tap into new demand and reduce costs by investing and locating operations in these regions.

Foreign companies should closely follow the development of the Hainan Free Trade Port, as well as of the other pilot free trade zones across China; and the implementation of Major National Strategies for Regional Development such as "The Guangdong-Hong Kong-Macao Greater Bay Area", "Beijing-Tianjin-Hebei Integration", "The Yangtze Economic Belt" and the "Chengdu-Chongqing Economic Rim".

These initiatives will become increasingly important in catalyzing foreign investment to those sectors and geographies that need it most and encouraging foreign companies to further localize their value chains.

\subsection{Inclusiveness and Public Services}

China is also looking to improve the quality of and accessibility to public services, including education, medical services, and-very importantly, given the country's demographic trends - elderly care. This will drive continued demand for high-quality foreign expertise and international best practices in the management and operation of facilities, training of personnel and provision of care services.

\subsection{Financial Services}

Over the past couple of years, the opening of China's financial sector has created many opportunities for foreign investors. For example, removing foreign ownership caps on banks, financial asset management companies (AMCs), securities, fund management, futures companies and life insurers; abolishing quota restrictions of QFII and RQFII; and implementation of stock and bond connect schemes.

The Plan talks about the continued opening of the banking, securities, insurance, fund and futures sectors, and taking steps to increase the connectivity between domestic and foreign capital markets.

Greater market access offers new opportunities for leading international financial institutions to provide a range of financial services including in the wealth management and retirement sectors which are expected to experience fast growth. Foreign players need to be clear about the advantages they offer relative to large and wellcapitalized domestic financial institutions. Recently announced transactions show that leading international financial institutions have been quick to take advantage of changes to further open China's financial service sectors. 
Green finance will play an important role in supporting China's transition to a low-carbon growth model and managing climate-related risks. On 1 March 2021, China's first local green finance regulations came into effect in Shenzhen, requiring the disclosure of information on the environmental impact of beneficiary enterprises, projects or assets invested. They are the second green finance regulations to be implemented in the world after the European Union. With targets now having been agreed upon for peak carbon dioxide emissions and carbon neutrality, the green finance market in China will develop quickly from what is already a comparatively large base. In the future, in addition to providing ESG-compliant options for global investors to support decarbonization by Chinese issuers, China is set to emerge as a leader in the regulation of green finance.

\section{Keys to Success}

For the first time in recent memory, a bigger challenge faced by MNCs is not the lack of opportunities in China, but rather the surge in misunderstanding and negative sentiment towards China as seen in many countries. ${ }^{9}$ Exploring the underlying reasons for this change is beyond the scope of this article. However, it is important to recognize that this phenomenon will continue to have an impact on the appetite for and pace with which some MNCs approach new opportunities. Business leaders have an important role to play in providing information about and advocating for the benefits of trade and investment with China in their home markets. This may include supporting efforts by reputable third parties to produce timely, fact-based analysis. It is important for economic consequences to be properly considered as the boundaries between collaboration, competition and rivalry are redrawn. Companies owe an obligation not only to their current shareholders but also to future generations to be an active participant in that debate.

At the same time, multilateral organizations, universities and think tanks will and need to play an increasingly important role in providing fact-based data and narrative which can be used to guide and support decision-making by MNCs on new opportunities which may not be well-understood by some stakeholders, particularly in developed markets.

Turning to success factors for MNCs in the China market, about which much has been written over the years. MNCs need to operate at "China speed" to be successful in the China market. This means being agile and responsive in what is a fast-changing and highly competitive market. In KPMG's 2019 Global CEO Survey, $58 \%$ of China CEOs agreed with the statement that "acting with agility is the new currency of business", while 63 percent said that increasing the use of partnerships with third-party firms is "the only way for our organization to achieve the agility it needs". More than ever, it is important to build trust and understanding about

${ }^{9}$ For example, see Pew Research Center, "American views of China", February 2021; KorberStiftung, "The Berlin Pulse", November 2020. 
your company with relevant government departments and industry organizations, as well as with customers, suppliers, employees and the community. Delivering highquality products and services which have a clear link to China's economic and social development objectives must be a fundamental element of any company's value proposition in China.

Change in China is breath-taking: it is happening constantly; it is happening across all facets of the economy and society; with different priorities in different regions. To follow, interpret and respond appropriately to changes in the external environment for their business operations, foreign companies need to build effective and empowered teams in market, work with reputable external consultants who have China experience and subject matter expertise, and become integrated in China's business ecosystem. This includes having constructive relationships with relevant government departments, regulators and industry bodies. These relationships can be conducive to MNCs influencing the development of new policies, laws, regulations, standards and industry development plans, as well as better understanding and adapting to institutional, policy and regulatory changes.

To be successful in China it will often make sense for foreign companies to partner with reputable local companies. Such collaborations may also be formed at the headquarters level, for example, through a Chinese strategic investor acquiring an equity interest in the foreign company and agreeing to help the foreign company enter the Chinese market.

Earlier in this article we talked about the advantages and necessity of undertaking R\&D and product and business model innovation in China. This will increasingly involve collaboration with local technology companies. In addition to looking at opportunities in the China market, MNCs should consider the business case for using their China operations to serve regional and BRI markets. Succeeding is no longer about making "in China" or "for China", but about making "with China" including in and for export to third-country markets. A heightened awareness of the importance of resilience will be an added driver of localization and regionalization of supply chains in the post-COVID era.

\section{Concluding Remarks}

International news media reporting about China when this article was written (March-April 2021) did not feature a substantive discussion about the business opportunities arising from the important transformation which is ongoing in China. In contrast, foreign holdings of onshore Chinese equities increased by RMB 12,978.61 trillion in 2020 representing a $61 \%$ year-on-year growth.

Institutional investors increasing their investments in onshore Chinese equities (and the growth in the value of those portfolios), reflects optimism about the earnings outlooks for issuers in different sectors. To what extent and how can foreign companies also benefit from opportunities arising from the development trends in China? These are the questions I have tried to address in this article. 
A lot of attention is paid to the importance of providing a level playing field for foreign companies. Foreign companies' experience of the progress which has been made addressing it is reflected in regular business sentiment surveys by foreign chambers of commerce in China. At the same time, we need to guard against conflating issues. China is not an "easy" market to be successful in, not least because it is highly competitive and dynamic. Just because a company is highly successful in its home market by no means guarantees success in China. As in any market, companies must work to establish, maintain and defend a unique and sustainable competitive advantage.

As a result of the success of its epidemic prevention and containment efforts, the Chinese economy has resumed an encouraging growth trajectory and momentum. Increasing the resilience of supply and its adaptiveness to domestic demand are cited in the "strategic direction" section of the Plan. At the same time, resumption of business travel to and from China is particularly important for foreign companies due to the higher reliance on expatriate staff, typically in management and technical roles where needs cannot be fully met from the local market. This will also be an important step in helping to bridge the information gap with head office decision-makers about new investment areas and project opportunities.

China's economic growth has contributed around 30\% of global growth in recent years. As a result, China's influence on the global economy has also become more pronounced, with the spillover effect of its economy and policies having an increasingly larger impact across countries. Based on forecasts, this situation is set to continue. Reflecting this and the factors discussed in this article, China will maintain and increase its importance to leading companies from around the world.

We are at an inflexion point in China's transition and integration in the world economy. On the one hand, there are new opportunities for foreign companies to seize in China's new development paradigm. On the other, there are new challenges for companies to face balancing the expectations of national governments and communities towards national security, economic growth, competitiveness and resilience and sustainable development. As was the case with the foreign companies that invested early in China's reform and opening-up, an opportunity will reward early movers who are able to adapt and align their value proposition and business strategies with China's economic and social development priorities and goals in the Plan. It is hoped that international co-operation in tackling climate change will usher a new wave of foreign investment in China and more "green" partnerships with Chinese companies in China and in developed and developing economies around the world. 


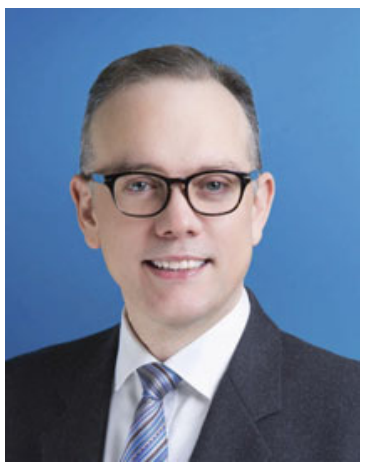

Vaughn Barber is Global Chair of KPMG's Global China Practice; Co-Head of Infrastructure, KPMG in China; Chair of the China-Australia Chamber of Commerce. Vaughn joined KPMG in Hong Kong from Australia in 1996 and became a partner in July 2000. After working in Hong Kong for nearly 15 years, Vaughn moved to Beijing and became Head of Outbound for KPMG China in 2011. In this capacity, and while he concurrently served as the Head of Deal Advisory, M\&A Tax for AsiaPacific, Vaughn continued working with Chinese state-owned and privately-owned companies to complete many landmark overseas acquisitions. A fluent Mandarin speaker, Vaughn has been a key member of the leadership team of the Global China Practice since its inception and was appointed Global Chair in July 2015.

Open Access This chapter is licensed under the terms of the Creative Commons AttributionNonCommercial-NoDerivatives 4.0 International License (http://creativecommons.org/licenses/bync-nd/4.0/), which permits any noncommercial use, sharing, distribution and reproduction in any medium or format, as long as you give appropriate credit to the original author(s) and the source, provide a link to the Creative Commons license and indicate if you modified the licensed material. You do not have permission under this license to share adapted material derived from this chapter or parts of it.

The images or other third party material in this chapter are included in the chapter's Creative Commons license, unless indicated otherwise in a credit line to the material. If material is not included in the chapter's Creative Commons license and your intended use is not permitted by statutory regulation or exceeds the permitted use, you will need to obtain permission directly from the copyright holder.

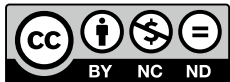

